\begin{tabular}{|c|c|c|}
\hline st & $\begin{array}{l}\text { CARADDE: Jurnal Pengabdian Kepada Masyarakat } \\
\text { https://journal.ilininstitute.com/index.php/caradde } \\
\text { Volume 1 | Nomor 2 | Februari | 2019 } \\
\text { e-ISSN: } 2621-7910 \text { dan p-ISSN: 2621-7961 } \\
\text { DOI: https://doi.org/10.31960/caradde.v1i2.106 }\end{array}$ & $\begin{array}{l}\text { IIN } \\
\text { GaradDE }\end{array}$ \\
\hline
\end{tabular}

\title{
Pemanfaatan Komputer untuk Pengembangan Media Pembelajaran Matematika sebagai Upaya Peningkatan Kompetensi Guru Sekolah Dasar
}

\author{
Putriaji Hendikawati $^{1)}$, Rahayu Budhiati Veronika ${ }^{2)}$, Stevanus Budi Waluya ${ }^{3)}$, Kristina \\ Wijayanti $^{4)}$
}

Keywords :
Alat peraga;
Matematika;
Kompetensi guru;
Corespondensi Author
Matematika, Jurusan Matematika
Gedung D7 Lt.1 FMIPA, Kampus
UNNES Sekaran Gunungpati,
Semarang 50299
Email:
putriaji.mat@mail.unnes.ac.id

History Artikel

Received: Oktober-2018; Reviewed: November-2018

Accepted: Desember-2018

Published: Februari-2019
Abstrak. Matematika adalah salah satu ilmu dasar yang diajarkan sejak sekolah dasar yang menekankan pada pemahaman konsep. Penggunaan media pembelajaran yang tepat adalah salah satu cara untuk menanamkan pemahaman konsep pada siswa. Tujuan kegiatan pengabdian yang dilaksanakan adalah memberikan pengetahuan dan memotivasi para guru Sekolah Dasar YPII Cabang Semarang untuk mengembangkan keterampilan dan kreatifitas dalam membuat media pembelajaran dengan menggunakan teknologi komputer. Metode yang digunakan untuk merealisasikan tujuan adalah dengan pelaksanaan ceramah dan demonstrasi berisi pelatihan dan simulasi, pendampingan dan workshop untuk membantu guru membuat media pembelajaran menggunakan bantuan computer serta pemberian penugasan di akhir kegiatan. Pada akhir kegiatan setiap guru menghasilkan sebuah produk media pembelajaran. Hasil yang diperoleh dari kegiatan ini adalah para guru merasakan manfaat kegiatan, memperoleh pengetahun baru, dapat membuat media pembelajaran sederhana dengan menggunakan bantuan komputer dan merasa tertantang untuk terus mengembangkan kemampuannya untuk memanfaatkan media komputer dalam membuat media pembelajaran.

This work is licensed under a Creative Commons Attribution

4.0 International License

\section{PENDAHULUAN}

Matematika adalah salah satu ilmu dasar yang diajarkan pada siswa sejak bangku sekolah dasar. Seiring berkembangnya teori belajar yang dikemukakan oleh beberapa ahli seperti Gagne, Bruner, Piaget, dan Zoltan Dienes, saat ini terjadi perubahan pada pembelajaran matematika utamanya di sekolah dasar yang menekankan pada pemahaman konsep dasar matematika. Bruner seperti dikutip oleh Suherman et al (2003: 43) menyatakan bahwa belajar matematika akan lebih berhasil apabila proses pengajaran diarahkan kepada konsep dan struktur yang termuat dalam pokok materi yang diajarkan, selain dari hubungan yang terkait antara konsep dan struktur. Suherman et al (2003: 56-57) sendiri menytarakan bahwa dalam pembelajaran matematika para siswa dibiasakan untuk memperoleh pemahaman melalui pengalaman tentang sifat-sifat yang dimiliki dan yang tidak dimiliki dari sekumpulan objek (abstraksi). Tanpa pemahaman, para siswa akan mengalamai kesulitan dalam mengikuti perkembangan 
matematika dan menyelesaikan persoalanpersoalan kontekstual.

Pemahaman akan konsep matematika salah satunya dapat dicapai dengan menggunakan media. Asosiasi teknologi dan komunikasi pendidikan (Association of Education and Communi-cation Technology/AECT) di Amerika membatasi media sebagai segala bentuk dan saluran yang digunakan orang untuk menyalurkan pesan/informasi. Menurut Gagne, media adalah berbagai jenis komponen yang dapat merangsang untuk belajar yang ada dalam lingkungan siswa. Menurut Briggs dalam Sadiman et al (2011:6), media adalah segala alat fisik yang dapat menyajikan pesan serta merangsang siswa untuk belajar. Reid dalam (Reeves, 1998: 1), menyatakan bahwa media termasuk sistem simbol yang beragam seperti cetak, grafik, animasi, audio, dan gambar bergerak.

Asosiasi Pendidikan Nasional
(Nasional Education Association memberikan pengertian bahwa media adalah bentuk komunikasi baik dengan cara tercatat maupun audiovisual serta perantaranya. Media yang digunakan dirancang untuk dapat dimanipulasi, dilihat, didengar dan dibaca. Menurut Kemp dan Dayton dalam Arsyad (2005:19), media pembelajaran dapat memenuhi tiga fungsi utama, yaitu: (1) memotivasi minat dan tindakan, (2) menyajikan informasi, dan (3) memberi instruksi. Sudjana \& Rivai dalam Arsyad (2005:24) mengemukakan beberapa manfaat media pembelajaran dalam proses belajar, yaitu membuat pengajaran lebih menarik sehingga menumbuhkan motivasi belajar, memperjelas isi dari bahan ajar sehingga dapat lebih dipahami, membuat metode mengajar lebih bervariasi, tidak hanya komunikasi verbal melalui penjelasan oleh guru, sehingga tidak membosankan, siswa dapat lebih banyak melakukan aktivitas sebab tidak hanya mendengarkan uraian guru, tetapi juga kegiatan lain seperti mengamati, melakukan, mendemonstrasikan, memerankan, dan lain-lain. Macam-macam media menurut Djamarah (2002: 141) dilihat dari jenisnya terdiri dari media audio, visual, dan media audiovisual.

Meningkatkan kompetensi guru merupakan salah satu langkah yang dapat dilakukan untuk mencapai peningkatan mutu pendidikan. Peran guru utamanya di pendidikan dasar memiliki peran yang besar untuk menanamkan konsep yang akan berguna untuk jenjang pendidikan yang lebih tinggi. Kemajuan teknologi yang pesat saat ini mengantarkan pada penggunaan dan pemanfaatan komputer dalam dunia Pendidikan. Kompetensi guru dapat ditingkatkan salah satunya dengan peningkatan keterampilan guru memanfaatkan komputer dalam kegiatan belajar mengajar. Komputer digunakan sebagai sarana dalam pembuatan media pembelajaran yang bermanfaat dalam proses pembuatan animasi. Menurut Thalmami (Budianto, 2011) animasi berarti menggerakkan, menghidupkan. Animasi adalah proses penciptaan efek gerak atau efek perubahan bentuk yang terjadi selama beberapa waktu. Animasi bisa berupa gerak sebuah objek dari tempat yang satu ke tempat yang lain, perubahan warna, atau perubahan bentuk (Salim, 2005: 1). Media pembelajaran yang memuat dan menampilkan bentuk animasi dapat menarik perhatian para siswa terhadap materi yang disampaikan oleh guru.

Menurut Davies \& Crowther (Suyanto, 2005: 340) penggunaan multimedia dalam proses belajar mengajar dapat meningkatkan efisiensi, meningkatkan motivasi, memfasilitasi belajar aktif, memfasilitasi belajar eksperimental, dan mengarahkan belajar yang berpusat pada siswa, serta memandu untuk belajar lebih baik. Penelitian mengenai penggunaan media yang dapat meningkatkan motivasi dan hasil belajar dilakukan oleh Rodgers, State, Milton, \& Medical (2016), Wu \& Tai (2016), Akcay, Durmaz, Tuysuz, \& Feyzioglu (2006), dan Aloraini (2012). Selain itu Almara'beh, Hilal, Amer, Ehab F., Sulieman (2015) menemukan bahwa penggunaan multimedia dalam pembelajaran memberikan banyak manfaat dan kemudahan.

Menurut Suherman (2003, 243), konsep abstrak yang baru diterima siswa akan mengendap, melekat, dan tahan lama bila siswa belajar melalui perbuatan dan dapat dimengerti siswa, bukan hanya melalui mengingat-ingat fakta. Hal inilah yang mendasari penggunakan media dalam pembelajaran matematika karena dengan menggunakan media atau alat peraga, konsep abstrak matematika dapat tersajikan dalam 
bentuk kongkrit, dan hubungan antara konsep abstrak matematika dengan benda-benda alam di sekitar akan lebih dapat dipahami, dan diharapkan dapat lebih memotivasi siswa untuk mempelajari matematika. Menurut Krismanto (2003, 10), alat peraga memungkinkan siswa dapat belajar secara aktif sehingga dapat menemukan berbagai hal yang terkait dengan pembelajaran, baik kognitif, psikomotorik, maupun afektif.

Upaya untuk meningkatkan kompetensi guru dapat dilakukan dengan meningkatkan pengetahuan dan pemahaman mengenai berbagai metode, pendekatan, serta strategi yang dapat diterapkan dalam pembelajaran di kelas terkait juga dengan pemanfaatan media pembelajaran untuk dapat memaksimalkan kemampuan dan pencapaian prestasi siswa. Berdasarkan hasil penelitian, penggunaan media dan alat peraga telah terbukti menunjukkan hasil yang baik terhadap hasil belajar siswa dan telah diterapkan pada beberapa bidang ilmu diantaranya psikologi (Al-Hariri \& AlHattami, 2017), seni (Yi, 2017), sekolah vokasi (Chen, Luo, Fang, \& Shieh, 2018), juga di sekolah dasar (Ciascai \& Marchis, 2008).

Yayasan Penyelenggaraan Ilahi Indonesia (YPII) adalah penyelenggara dan pengelola sekolah-sekolah yang dirintis oleh Suster-Suster Penyelenggaraan Ilahi (PI) sejak tahun 1934. YPII Kantor Cabang Semarang membawahi 13 Unit Sekolahan dengan 4 Jenjang Sekolah (TK, SD, SMP dan SMA). Saat ini permasalahan yang dihadapi oleh guru-guru Sekolah Dasar yang bernaung di bawah YPII Cabang Semarang adalah mereka masih mengalami kesulitan untuk mengembangkan media untuk mengajarkan konsep matematika kepada siswanya. Berkaitan dengan masalah tersebut, para guru ingin meningkatkan dan mengembangkan kemampuan membuat media pembelajaran matematika yang kreatif bagi siswanya dengan menggunakan bantuan teknologi komputer, namun hal ini terkendala dengan masih minimnya pengetahuan akan pembuatan media pembelajaran yang dimiliki oleh guru. Guru-guru tertarik untuk mempelajari lebih dalam mengenai pembuatan media pembelajaran matematika kreatif dengan menggunakan bantuan komputer. Dalam pengabdian ini, media yang digunakan berupa media video yang dibuat oleh guru yang digunakan untuk menjelaskan suatu materi atau konsep tertentu terkait materi matematika yang dipelajari. Untuk memfasilitasi hal tersebut maka dilaksanakan pelatihan kepada guru-guru Sekolah Dasar yang tergabung dalam YPII yang ada di Semarang mengenai pembuatan alat peraga dalam hal ini dengan mengunakan komputer untuk mendukung visi dan misi YPII yaitu pembelajaran matematika kreatif dengan pendekatan konstruktivisme serta bagaimana menerapkannya dalam pembelajaran.

\section{METODE}

Sasaran dari kegiatan ini adalah para guru-guru sekolah dasar yang bernaung di bawah YPII yang ada di Kota Semarang. Peserta yang hadir adalah 37 orang guru yang berasal dari 5 sekolah dasar yang berada di bawah YPII yaitu SD Kebon Dalem 1, SD Kebon Dalem 2, dan SD Marsudi Utami dari kota Semarang, SD Cahaya Nur Kudus, dan SD Pangudi Utami Temanggung.

Secara garis besar kerangka pemecahan masalah dalam pengabdian masyarakat yang telah dilaksanakan, dilakukan dalam tiga tahap yaitu: (1) Pengarahan yang disampaikan melalui ceramah yang diselingi dengan dialog terkait dengan pembuatan media pembelajaran matematika dengan komputer. Pengarahan dilakukan untuk memperkenalkan pada guru mengenai pentingnya memanfaatkan kemajuan teknologi berupa telepon pintar, kamera, komputer/laptop dan software pengembangan media untuk membuat media pembelajaran; (2) Pemberian contoh simulasi pembuatan media pembelajaran yang mengimplementasikan pemanfaatan teknologi komunikasi dan media internet dalam pembelajaran matematika di sekolah dasar; dan (3) Pendampingan dan pelatihan mulai dari perencanaan, perancangan dan pembuatan media pembelajaran matematika yang mengacu pada pembelajaran matematika kreatif dengan memanfaatkan komputer dan software pembuatan media.

Metode yang digunakan dalam kegiatan pengabdian ini adalah: (a) Ceramah untuk memberikan informasi dan manfaat tentang media pembelajaran matematika, pemanfaatan teknologi informasi sebagai media dan sarana pembuatan media pembelajaran matematika dalam upaya untuk 
meningkatkan kemampuan matematika siswa sekolah dasar; (b) Demonstrasi dilaksanakan untuk menunjukkan langkah-langkah pembuatan media matematika dengan memanfaatkan komputer dan software pembuatan media; (c) Penugasan kepada para peserta kegiatan untuk membuat media pembelajaran dengan memanfaatkan komputer sesuai dengan kurikulum dan tingkat kesulitan materi pelajaran matematika yang dilaksanakan di kelas. Selanjutnya guru diminta untuk membuat produk media pembelajaran matematika sederhana dengan memanfaatkan komputer sesuai dengan materi dan tingkatan kelas yang diampu.

\section{HASIL DAN PEMBAHASAN}

Kegiatan pelatihan, pendampingan dan workshop ini dilaksanakan dalam 2 kali pertemuan bertempat di SD Kebon Dalem 2 yang beralamat di Jalan Arum Sari Raya, Kelurahan Sambiroto, Kecamatan Tembalang, Kota Semarang Jawa Tengah. Realisasi pemecahan masalah dilaksanakan dengan langkah-langkah berikut.

Pelaksanaan pelatihan, pendampingan dan workshop: penyampaian materi mengenai Media Pembelajaran matematika, Pentingnya bagi guru sekolah dasar untuk dapat membuat media pembelajaran matematika yang baik dan menarik, pengenalan dan pemberian contoh bentuk media yang disusun dengan bantuan komputer, simulasi dan pendampingan pelatihan pembuatan media pembelajaran matematika dengan memanfaatkan teknologi komputer. Selanjutnya diberikan pelatihan mengenai perancangan dan pembuatan media pembelajaran bagi guru YPII.

Sebagai tindak lanjut dari kegiatan pelatihan, pendampingan dan workshop ini selanjutnya setiap guru peserta diberi penugasan untuk membuat media pembelajaran lengkap dengan menggunakan bantuan komputer dan memanfaatkan software Adobe Flash maupun Geogebra. Pembuatan media pembelajaran ini diselesaikan oleh masing-masing guru peserta pelatihan secara individu, sebagai implementasi hasil pelatihan pembuatan media pembelajaran matematika dengan menggunakan bantuan komputer. Hasil produk dari guru peserta selanjutnya diintegrasikan dalam kegiatan pembelajaran di kelas. Produk media yang dihasilkan selanjutnya direview oleh ahli media untuk memperoleh masukan dan saran untuk perbaikan media sehingga menjadi produk dari kegiatan pengabdian ini.

Pertemuan pertama dilaksanakan pada tanggal 4 Agustus 2018. Dalam kegiatan pertemuan pertama ini telah diinformasikan beberapa materi yang berkaitan dengan media pembelajaran matematika dengan menggunakan komputer, yaitu 1) Manfaat media pembelajaran matematika, 2) Pemanfaatan teknologi informasi sebagai media dan sarana pembuatan media pembelajaran matematika dalam upaya untuk meningkatkan kemampuan matematika siswa sekolah dasar, 3) Demonstrasi dan simulasi menunjukkan langkah-langkah pembuatan media matematika dengan memanfaatkan komputer dan software pembuatan media, dan 4) Pelatihan dan praktek pembuatan media pembelajaran sesuai dengan kurikulum dan tingkat kesulitan materi pelajaran matematika yang dilaksanakan di kelas. Pada pertemuan hari pertama tim pengabdi menyampaikan informasi mengenai mengenai media pembelajaran matematika dengan bantuan komputer. Pelatihan dan pendampingan dilaksanakan oleh tim pengabdian dengan mengundang seorang narasumber yang ahli di bidang media Pendidikan yaitu Dr.rer.nat. Adi Nur Cahyono, M.Pd.

Pada pelatihan penyusunan media pembelajaran pada mata pelajaran matematika, ditampilkan dan disimulasikan contoh media pembelajaran untuk mata pelajaran matematika yang dibuat dengan memanfaatkan teknologi informasi termasuk komputer. Dalam kegiatan ini guru secara individu diminta untuk mengidentifikasi materi pembelajaran matematika di kelas sesuai dengan tingkatan kelas yang memerlukan bantuan media pembelajaran dan dapat disusun media dengan bantuan komputer, dilanjutkan dengan membuat rancangan media pembelajaran dengan menggunakan bantuan komputer dan software pembuatan media seperti Adobe Flash dan Geogebra. Guru diajak untuk memahami dan menggali kemampuannya untuk merancang dan membuat media untuk membelajarkan dan menjelaskan konsep 
matematika pada siswa dengan bantuan komputer. Selanjutnya dilakukan sharing diantara para guru peserta pelatihan untuk kemudian saling melengkapi dan berdiskusi mengenai rancangan bentuk media pembelajaran yang akan disusun serta melakukan kolaborasi penyusunan media bagi para guru dengan jenjang kelas yang sama atau materi pembelajaran yang sama. Selama kegiatan pelatihan para peserta terlihat antusias terbukti dengan banyaknya muncul pertanyaan seputar materi yang disampaikan serta keaktifan peserta dalam kegiatan praktek pembuatan media pembelajaran yang disampaikan oleh tim pengabdi.

Pertemuan kedua kegiatan pengabdian dilaksanakan pada tanggal 11 Agustus 2018, melanjutkan kegiatan menyelesaikan penugasan yang telah diberikan sebelumnya. Setelah menerima materi dari pengabdi, peserta diminta untuk merancang dan membuat media pembelajaran yang sesuai dengan materi yang diampu di kelas. Para peserta diminta untuk memilih materi dan indikator pembelajaran yang akan dibuat media pembelajarannya. Selanjutnya peserta diberi kesempatan untuk mengajukan pertanyaan. Para guru melakukan perancangan dan pembuatan sebuah media pembelajaran matematika sederhana dengan memanfaatkan komputer sesuai dengan materi dan tingkatan kelas yang diampunya. Dalam kegiatan dilaksanakan pembuatan media pembelajaran, dilakukan pula diskusi terkait kesulitan yang dihadapi guru dalam pembuatan media menggunakan komputer dan refleksi terhadap kegiatan yang telah dilakukan.

Setelah menerima materi dari pengabdi, peserta diberi penugasan untuk merancang dan membuat media pembelajaran matematika sesuai materi pada tingkatan kelas yang diampu dengan menggunakan bantuan komputer. Dalam kegiatan ini, guru peserta pelatihan secara individu diminta untuk mengidentifikasi materi dalam pembelajaran matematika di kelas yang dialaminya yang sekiranya sesuai dan dapat diarahkan untuk pembuatan media pembelajaran dengan komputer. Pada kegiatan pertemuan kedua, beberapa peserta yang terpilih mempraktekkan media pembelajaran yang telah dibuat untuk kemudian diberikan masukan dan komentar dari peserta lain. Setelah selesai dilaksanakan evaluasi dan refleksi yang dipandu oleh tim pengabdian pada masyarakat, disampaikan dalam evaluasi dan refleksi diperoleh kesimpulan bahwa beberapa hal yang disampaikan dalam sharing terkait beberapa kesulitan yang ditemui dan dialami para guru dalam perancangan dan pembuatan perangkat pembelajaran dengan bantuan komputer yang telah dilakukan. Selanjutnya dilakukan sharing diantara para guru peserta pelatihan untuk kemudian saling melengkapi dan berdiskusi mengenai berbagai pengalaman serta kesulitan dan kendala saat membuat media pembelajaran dengan computer. Selanjutnya peserta diberi kesempatan untuk mengajukan melakukan tanya jawab. Pada saat peserta diberikan kesempatan untuk mengajukan pertanyaan, peserta terlihat sangat antusias untuk menanyakan hal-hal yang berkaitan dengan pembuatan media pembelajaran beserta software dan aplikasi terbaru yang dapat dimanfaatkan dalam pembuatan media dengan komputer. Selain itu para peserta juga menyampaikan berbagai pertanyaan yang berkaitan dengan permasalahan pembelajaran matematika yang ditemui di lapangan dan tips serta trik membuat media pembelajaran yang baik dan bagus yang dapat memotivasi siswa memperlajari matematika. Sebelum kegiatan diakhiri, peserta diberi tugas mandiri untuk menyempurnakan media pembelajaran dengan menggunakan komputer.

Dalam kegiatan pengabdian ini, media pembelajaran yang berisi materi pelajaran dibuat dengan menggunakan software Adobe Flash CS3 yang dapat digunakan untuk membuat animasi baik yang sederhana hingga kompleks. Adobe flash dapat menggabungkan gambar, suara, dan video ke dalam animasi yang dibuat. Adobe Flash CS3 adalah satu software dari perusahaan adobe, Inc. yang banyak diminati oleh kebanyakan orang diminati karena kehandalannya yang berkaitan untuk pembuatan film kartun, banner iklan, web site, presentasi, game, dan lain sebagainya (Andi dalam Husril, 2011). Flash dapat pula dikombinasikan dengan program lain, flash juga dapat dikombinasikan dengan bahasa pemrograman, dan ukuran akhir dari file dengan hasil animasinya relative kecil merupakan keandalan adobe flash CS3 
dibandingkan dengan program lain (Nugraha dalam Husril, 2011).

Sebagai tindak lanjut dari kegiatan pelatihan, pendampingan dan workshop ini selanjutnya setiap guru peserta diberi tugas mandiri untuk memperbaiki dan menyusun media pembelajaran sesuai dengan masukan saran dan hasil evaluasi dari kegiatan sebelumnya. Produk yang merupakan hasil penugasan ini diselesaikan oleh masingmasing guru peserta pelatihan secara individu, sebagai implementasi hasil pelatihan dan workshop pembuatan media pembelajaran matematika dengan menggunakan komputer.

Di akhir kegiatan seluruh peserta menyepakati bahwa jika dalam waktu ke depan diselenggarakan kegiatan semacam program ini mereka bersedia untuk mengikuti kembali, karena kebermanfaatan kegiatan ini. Secara umum pelaksanaan pengabdian sudah berjalan dengan baik, ada rencana tindak lanjut baik dari tim pengabdian secara terbuka mempersilahkan para peserta untuk menjalin komunikasi dengan perguruan tinggi dalam hal ini Jurusan Matematika FMIPA Universitas Negeri Semarang dalam mencari solusi dari masalah pembelajaran matematika yang ditemui dalam kelas. Pada tahap lanjut diharapkan peserta dapat mensosialisasikan mengenai pembuatan media pembelajaran matematika dengan menggunakan bantuan komputer kepada rekan guru di sekolah lain serta dapat melaksanakan serta

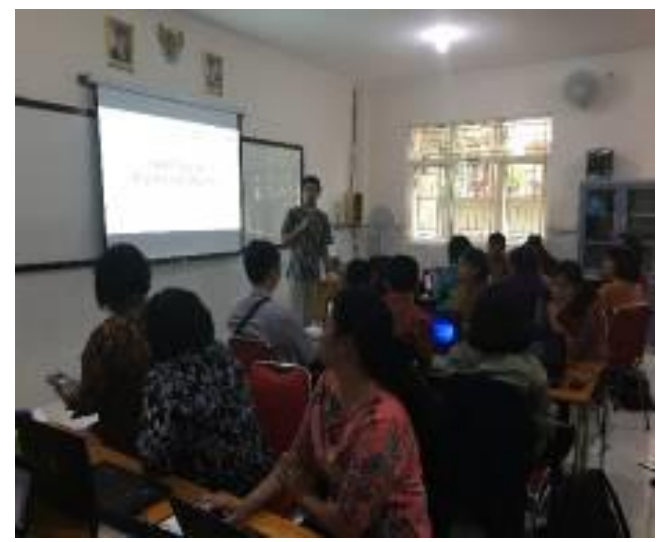

mengimplementasikan ilmu dan media pembelajaran yang telah dibuat di kelasnya masing-masing.

Pada akhir kegiatan, hasil yang dipacai adalah para guru YPII yang mengikuti kegiatan mengalami peningkatan pengetahuan dan keterampilan dalam membuat media pembelajaran menggunakan komputer. Para guru juga telah dapat menghasilkan produk media pembelajaran sederhana yang dibuat dengan bantuan komputer. Hasil yang dicapai dari kegiatan yang telah dilaksanakan telah memenuhi target kegiatan yang ditetapkan. Para guru peserta kegiatan telah dapat membuat media pembelajaran dengan bantuan computer yang memuat berbagai materi pembelajaran khususnya matematika yang dapat digunakan untuk mengajarkan konsep dalam kegiatan belajar mengajar di kelas. Produk media yang dihasilkan sebagian besar masih dalam bentuk tampilan sederhana, namun telah dapat menyampaikan konsep materi sesuai tujuan pembelajaran. Keunggulan dari media yang dihasilkan adalah dapat digunakan dalam pembelajaran tidak hanya di kelas namun juga di rumah (jika diunggah secara online) sehingga sangat fleksibel digunakan untuk belajar sesuai dengan kemampuan siswa tanpa terbatas ruang dan waktu.

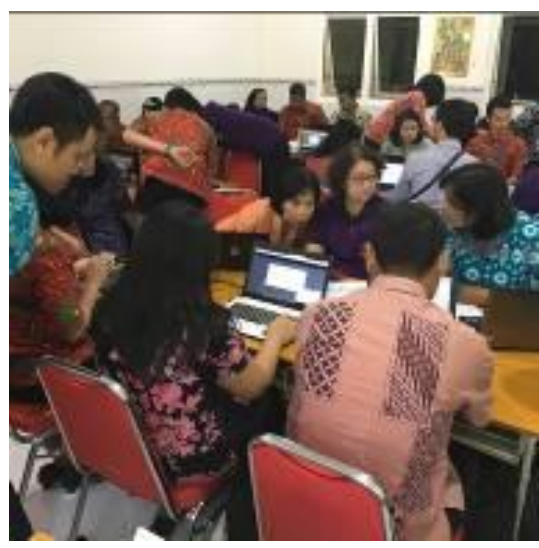

Gambar 1: (a) Tim Menyampaikan Materi dalam Kegiatan Pelatihan, (b) Peserta Pelatihan melakukan Simulasi Pembuatan Media dengan Komputer

\section{SIMPULAN DAN SARAN}

Berdasarkan pelaksanaan kegiatan secara menyeluruh, dapat disimpulkan bahwa strategi meningkatkan keterampilan guruguru khususnya di sekolah dasar YPII cabang 
Hendikawati, Veronika, Waluya, Wijayanti. Pemanfaatan Komputer untuk Pengembangan

Semarang dalam memanfaatkan media dalam pembelajaran matematika dilakukan dengan melakukan sosialisasi mengenai manfaat dan kegunaan media dalam hal ini dititikberatkan pada media pembelajaran matematika menggunakan komputer serta demonstrasi dan pelatihan serta workshop untuk merancang dan membuat media pembelajaran matematika dengan menggunakan bantuan komputer dalam pelajaran Matematika.

Untuk meningkatkan pemahaman para guru mengenai alat peraga dan media pembelajaran matematika serta pembuatan dan implementasinya dalam pembelajaran dapat diperoleh melalui sosialisasi dan pelatihan. Keuntungan dapat membuat sendiri alat peraga dan media pembelajaran matematika bagi guru adalah dapat langsung menerapkan hasil medianya pada siswa yang diampu dengan menyesuaikan keadaan dan kondisi siswa.

Berdasarkan kegiatan sosialisasi yang telah dilaksanakan maka untuk kegiatan selanjutnya perlu adanya komunikasi antara perguruan tinggi dan guru dalam kegiatan pengabdian maupun kegiatan lainnya yang bertujuan untuk menyelesaikan masalah pembelajaran matematika di kelas. Kegiatan ini masih perlu dilanjutkan dengan pendampingan, pelatihan dan motivasi bagi guru untuk terus berlatih dan mengasah keterampilan untuk membuat media pembelajaran matematika sendiri lebih kreatif sehingga keberlanjutan kegiatan ini dapat terarah sesuai dengan tujuan yang diharapkan.

\section{DAFTAR RUJUKAN}

Akcay, H., Durmaz, A., Tuysuz, C., \& Feyzioglu, B. (2006). Effects of Computer Based Learning on Students' Attitudes and Achievements towards Analytical Chemistry. The Turkish Online Journal of Educational Technology, $5(1)$, 44-48. https://doi.org/10.1111/j.14678535.2006.00603.x

Al-Hariri, M. T., \& Al-Hattami, A. A. (2017). Impact of students' use of technology on their learning achievements in physiology courses at the University of Dammam. Journal of Taibah University Medical Sciences, $\quad$ 12(1), 82-85. https://doi.org/10.1016/j.jtumed.20 16.07.004

Almara'beh, Hilal, Amer, Ehab F., Sulieman, A. (2015). The Effectiveness of Multimedia Learning Tools in Education. International Journal of Advanced Research in Computer Science and Software Engineering, 5(12), 761764.

Aloraini, S. (2012). The impact of using multimedia on students' academic achievement in the College of Education at King Saud University. Journal of King Saud University Languages and Translation, 24(2), 7582.

https://doi.org/10.1016/j.jksult.201 2.05.002

Arsyad, A. 2005. Media Pembelajaran. Jakarta: Raja Grafindo Persada.

Budianto, H. 2011. Efektifitas Penggunaan Media Presentasi Animasi Flash Terhadap Peningkatan Hasil Belajar Siswa Pada Mata Pelajaran Fisika : Kuasi Ekperimen terhadap Siswa SMA PGII 1 Bandung Kelas IX. Skripsi Universitas Pendidikan Indonesia.

Chen, Y. F., Luo, Y. Z., Fang, X., \& Shieh, C. J. (2018). Effects of the application of computer multimedia teaching to automobile vocational education on students' learning satisfaction and learning outcome. Eurasia Journal of Mathematics, Science and Technology Education, 14(7), 3293-3300.

https://doi.org/10.29333/ejmste/91 245

Ciascai, L., \& Marchis, I. (2008). Multimedia in Primary and Secondary School, 1(2).

Djamarah, S.B \& A. Zain. 2002. Strategi Belajar Mengajar. Jakarta: Rineka Cipta.

Husril. 2011. Desain Media Pembelajaran Animasi Berbasis Adobe Flash CS3 Pada Mata Kuliah Instalasi Listrik 2. Journal MEDTEK, 3/2: 5-6 
Reeves, TC. 1998. The Impact of Media and Technology in Schools (section 1). The University of Georgia. Tersedia di http://treeves.coe.uga.edu/edit6900 / BertelsmannReeves98.pdf [diakses 17-01-2013]

Rodgers, D. L., State, P., Milton, H., \& Medical, S. H. (2016). Document Page: THE EFFECT OF INSTRUCTIONAL MEDIA ON LEARNER MOTIV ... Page 1 of 9, (March).

Sadiman, A.S., dkk. 2011. Media Pendidikan Pengertian, Pengembangan, dan Pemanfaatannya. Jakarta: PT. Raja Grafindo Persada.

Salim, A. 2005. Trik Membuat Animasi Teks dengan Macromedia Flash MX 2004. Jakarta: Elex Media Komputindo.

Suherman, E. 2003. Strategi Pembelajaran Matematika Kontemporer. Bandung: Jurusan Pendidikan Matematika FMIPA Universitas Pendidikan Indonesia.
Suyanto, M. 2005. Multimedia Alat untuk Meningkatkan Keunggulan Bersaing. Yogyakarat: Andi Offset.

Wu, T. J., \& Tai, Y. N. (2016). Effects of multimedia information technology integrated Multi-Sensory instruction on students' learning motivation and outcome. Eurasia Journal of Mathematics, Science and Technology Education, 12(4), 1065-1074. https://doi.org/10.12973/eurasia.20 $16.1552 \mathrm{a}$

Yi, G. (2017). Design research on the network multimedia courseware for artdesign teaching. Eurasia Journal of Mathematics, Science and Technology Education, 13(12), 7885-7892. https://doi.org/10.12973/ejmste/80 722 